\title{
Comments on taxonomical status of three gobiid nominal species (genus Gobius) described from Brazilian coast (Teleostei: Gobiiformes: Gobiidae)
}

\author{
Rodrigo Antunes Caires ${ }^{1}$ \\ 1 Universidade de São Paulo (USP), Museu de Zoologia (MZUSP). São Paulo, SP, Brasil. \\ ORCID: http://orcid.org/0000-0002-9918-3972. E-mail: rodricaires@yahoo.com.br
}

\begin{abstract}
Three species described and currently included in the genus Gobius from the Brazilian coast are herein discussed. Gobius uranoscopus Sauvage is regarded as junior synonym of Bathygobius soporator based on information on holotype deposited in Muséum National d'Histoire Naturelle, Paris; G. silveiraemartinsi lhering, known only in Rio Grande do Sul was erected based on a short description, and type material is not available, but I considered that it is junior synonym of Ctenogobius shufeldti; Gobius boekeri Ahl, 1931, described from the coast of Pará, Brazil, is a junior synonym of Gobionellus oceanicus, as both taxa are virtually identical in meristic characters and presumable morphometric differences that Ahl used to substantiate the validity of his new species actually fall into the morphometric range observed in $G$. oceanicus specimens and may be attributable to individual variation and to the image quality by Ahl's original description.
\end{abstract}

Key-Words. Gobiids; Taxonomy; Brazilian EEZ; Ihering; Sauvage; Ahl; Synonymy.

\section{INTRODUCTION}

Family Gobiidae (gobies) is the most diverse group of acanthomorph fishes, with at least 189 genera and more than 1,700 species (Nelson et al., 2016), and has a pivotal role in coral reef, marine and brackish environments. Besides its extraordinary diversity, the taxonomy of gobies is not yet satisfactorily known, with several new species being discovered each year and many others awaiting description. The Brazilian EEZ has reported 28 genera and 51 species to date (Moura et al., 2003).

Gobius was erected by Linnaeus (1758) to include seven species he had diagnosed based on fused pelvic fin rays, forming a disk (Pinnae ventrales unitae). In prior studies on gobiids, most described taxa were put into this genus (including taxa described from the Brazilian coast), which then became a large wastebasket of poorly defined groups, although many of such taxa have been allocated to other genera (for a historical perspective of gobiid taxonomy, see Koumans, 1931). Today the genus Gobius refers to taxa circumscribed to Baltic, Black, Mediterranean and North Seas, and eastern Atlantic as well (for more information, see Pinchuk, 1976, 1977; Miller, 1986), and thus other species were removed and an immense wealth of new genera have been created. On the other hand, three nominal species of Gobius were described from the Brazilian coast: Gobius uranoscopus, Sauvage, 1882; G. silveiraemartinsi lhering, 1893; and G. boekeri Ahl, 1931 , but they have not been treated since then, so these names continued valid despite their real taxonomic status remained unknown to date. This study aims to discuss the taxonomy of the abovementioned nominal species.

\section{MATERIALS AND METHODS}

Descriptions of morphological data, whenever not mentioning the original description, are provided according to Murdy \& Hoese (2003) and Tornabene et al. (2010). Institutional abbreviations are in accordance with Eschmeyer and Fricke (2015). Abbreviations in the text are as follows: $\mathrm{SL}=$ standard length; $\mathrm{HL}$ = head length; $\mathrm{D}$. = dorsal fin elements (spines and rays); A. = anal fin elements (spines and rays); $P .=$ pectoral fin rays; $\|$ = scales on longitudinal row; $G R=$ gill rakers (upper + lower). Unknown data from the original description or for lack of type material for each nominal species is indicated along with the text by question marks ("???").

Morphometric data on species were taken mainly from photographs and images. Comparative material of Gobionellus oceanicus deposited in Museum of Zoology, University of São Paulo, Brazil was also examined. 


\section{RESULTS AND DISCUSSION}

\section{Gobius uranoscopus Sauvage, 1882 syn. nov. (Fig. 1)}

Material examined: MNHN 4251-A, holotype, $57 \mathrm{~mm} \mathrm{SL}$, photographs in lateral view (C. Ferrara, 2014).

Description: SL 65 mm; HL 33.7\% SL; D. VI.10; A. 9; P. ???; II 42; GR ???.

The only information on type locality of this species is the term "Brésil", written in the original description. The MNHN's website informs that holotype would have been taken in $10^{\circ} \mathrm{S}-30^{\circ} \mathrm{W}$, but this is probably wrong since such coordinates are located outside the Brazilian EEZ.

The original description of Gobius uranoscopus is not much detailed, but counts of scales in longitudinal row (98 scales) are clearly wrong since only Sicydium plumieri, among western Atlantic gobiids, possesses so many scales on flanks (Watson, 2000). Also, G. uranoscopus does not have long, comb-like teeth on upper jaw and five curved teeth on each side of lower jaw as in Sicydium. Further examination on images of the holotype revealed this specimen has about 42 scales on longitudinal row over flanks.

In MNHN's website, Gobius uranoscopus was recognized as an unidentified Bathygobius, which is confirmed herein based on its head morphology and the presence of upper pectoral fin rays (Fig. 1) as detached silk-like filaments (Miller \& Smith, 1989; Murdy \& Hoese, 2003). Four Bathygobius species have been reported from the Brazilian EEZ: B. antilliensis, Tornabene, Baldwin, Weigt \& Pezold, 2010, in Atol das Rocas; B. brasiliensis, CarvalhoFilho \& Araújo, 2017, in Atol das Rocas and Fernando de Noronha; B. geminatus, Tornabene, Baldwin, Weigt \& Pezold, 2010, in western North Atlantic, coast of Espírito Santo; and B. soporator, Valenciennes, 1837, in western North Atlantic, coast of Santa Catarina. It is rather implausible that Gobius uranoscopus holotype has been taken in Atol das Rocas or Fernando de Noronha because most Brazilian material deposited in MNHN was taken by Delalande, who never visited those islands. Therefore,

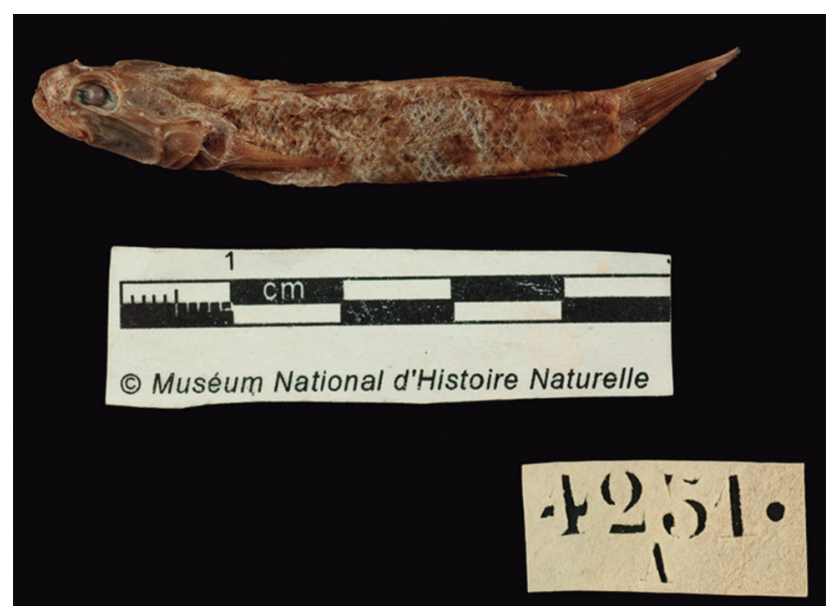

Figure 1. Holotype of Gobius uranoscopus Sauvage. MNHN 251-A, holotype, 57 mm SL, in lateral view. Photograph by C. Ferrara, 2014. the affiliation of G. uranoscopus with Bathygobius antilliensis and G. brasiliensis may be rejected.

Bathygobius geminatus is distinguished from B. soporator by the presence of a row of round black spots ventrolaterally on trunk (over light yellow background) and 36-38 scales on longitudinal row, whereas B. soporator has rather dull black coloration with irregular markings on trunk (without row of black spots), black diagonal line along first dorsal fin and 38-44 scales on longitudinal row. Although the pigmentation of G. uranoscopus specimen is faded due to long period under preservation, the row of black spots typical of $B$. geminatus is not visible in this specimen; based on this feature and scale counts, G. uranoscopius is herein regarded as junior synonym of Bathygobius soporator.

\section{Gobius silveiraemartinsi lhering, 1893 syn. nov.}

Material examined: not available.

Description: SL 35 mm; HL 28.6\% SL; D. V.14; A. 13; P. 15; II ???; GR ???.

This species has been described based on two specimens taken in southern Brazilian coast, (Camaquã, Rio Grande do Sul state). The type material of this species is unknown and the original description is poorly detailed and without any image. Ihering stated G. silveiraemartinsi specimens present seven spines in first dorsal fin, 2 spines and 11 rays in second dorsal fin, two spines and 11 rays in first anal fin, and 15 pectoral fin rays. The presence of seven spines are typical of gobiid subfamily Gobiosomatinae (Birdsong, 1975), but no member of this subfamily encountered in Brazil possesses only 15 pectoral fin rays, fin counts provided by lhering are possibly erroneous, and, evidently, Gobius silveiraemertinsi probably is not a gobiosomatinae, since all gobiosomatines reported from southern Brazilian coast present different values of dorsal, anal and pectoral fins, such as Microgobius meeki, Evermann \& Marsh (D. VII+11-12; A. 9-10; P. 17-21; Birdsong, 1981), and Gobiosoma hemygymnum (Eigenmann \& Eigenmann, 1888) (D. VII+16-18; A. 16-18; P. 19-23; Van Tassell et al., 2015).

Other gobiid species assigned to southern Brazilian coast are: Awaous tajasica (Lichtenstein, 1822); Bathygobius soporator, Ctenogobius boleosoma (Jordan \& Gilbert, 1882); C. shufeldti (Jordan \& Eigenmann, 1887); Evorthodus lyricus (Girard, 1858); Gobioides broussonnetii (Lacépède, 1800); Gobionellus oceanicus (Pallas, 1770); and G. stomatus (Starks, 1913) (see also Fischer et al., 2011; Malabarba et al., 2013). Gobius silveiraemartinsi differs from Awaous tajasica by having larger eye (25\% of $\mathrm{HL}$ vs. less than $20 \%$ of $\mathrm{HL}$ ), more than 11 anal fin rays, and pigmentation without black oblique lines behind the pectoral fin base (present in Awaous; Watson, 1996); from Evorthodus lyricus by the absence of two round black blotches on the caudal fin base (present in E. lyricus; Murdy \& Hoese, 2003); from Gobioides broussonnetii by having large eye (about $25 \%$ HL vs. $5 \%$ or less; Murdy, 1998); from Gobionellus oceanicus by possessing about 


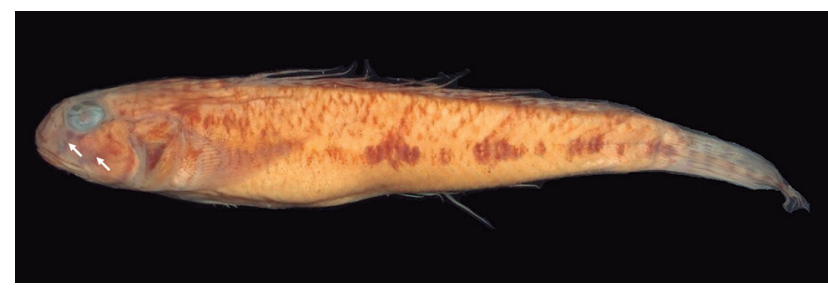

Figure 2. Ctenogobius shufeldti, MZUSP 14346, Rio Grande do Sul, Lagoa de Tramandaí, female, $55.3 \mathrm{~mm} \mathrm{SL}$, in lateral view. White arrows indicate brown oblique stripes on head below eye that are diagnostic for this species.

15 pectoral rays (vs. 16-20) and presumably less than 14 dorsal fin rays and 15 anal fin rays (vs., respectively, 14 and 15 rays); from $G$. stomatus by the absence of vertical dark markings on flanks (Pezold, 2004), and from Ctenogobius boleosoma by not presenting humeral black blotch (Ginsburg, 1932; Gilbert \& Randall, 1979).

Gobius silveiraemartinsi is mostly similar to Ctenogobius shufeldti in pigmentation, particularly in the presence of "Von Augen zu Munde laufen zwei kurze braunen Streifen, über den Backen ein dritter längerer (p. 34)"; the presence of two dark brown stripes from eye to upper jaw, the largest one on cheek, is typical of C. shufeldti (Fig. 2) and it is shared only with C. sagitulla from eastern Pacific (Ginsburg, 1932). Regardless of the disagreement on counts of first dorsal fin spines between these taxa, G. silveiraemartinsi is herein regarded as junior synonym of Ctenogobius shufeldti.

\section{Gobius boekeri Ahl, 1931 syn. nov. (Fig. 3; Table 1)}

Material examined: not available.

Description: SL 141 mm; HL 12.9\% SL; D. VI.15; A. 15; P. ???; II 82; GR ???.

Holotype of this species was taken in Soure, Marajó, in the state of Pará, Brazil, but this type specimen, which would have been sent to Zoologisches Museum, Berlin $(\mathrm{ZMB})$, is presumably lost. On the other hand, the description Ahl provided for this species is very straightforward and included a decent illustration of the type specimen. The author considered his new species quite similar to Gobionellus oceanicus, but argued his taxa differ from that species by having a more elongated body and body depth larger on dorsal fin origin. However, further examination of the original description and image compared with the material of Gobionellus oceanicus (see also Pezold, 2004) revealed that body depth and other morphometric values fall into the range, which is observed

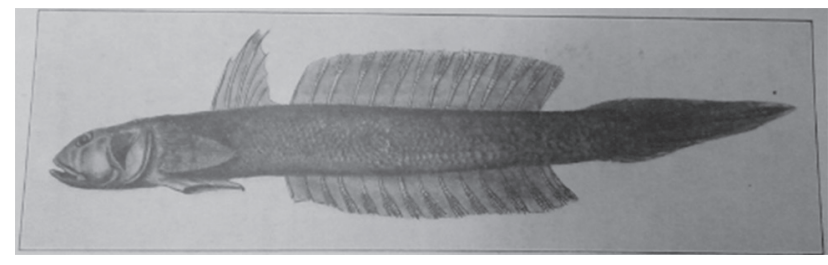

Figure 3. Gobius boekeri Ahl, image taken from the original description.
Table 1. Selected morphometric data of Gobius boekeri compared with examined Gobionellus oceanicus specimens and data from Pezold (2004).

\begin{tabular}{lccc}
\hline & Gobius boekeri & $\begin{array}{c}\text { Gobionellus oceanicus } \\
\text { MZUSP (N=18) }\end{array}$ & $\begin{array}{c}\text { Gobionellus oceanicus } \\
\text { (data from Pezold 2004) }\end{array}$ \\
\hline SL (mm) & 106.2 & $66.3-173.1$ & $35.9-153.8$ \\
\%SL & & & \\
Body depth & 12.7 & $10.2-17.0$ & $10.4-17.1$ \\
Caudal-peduncle height & 9.1 & $7.6-9.3$ & $7.1-10.7$ \\
Caudal-peduncle length & 13.3 & $7.9-12.8$ & $7.2-10.9$ \\
Head length & 16.4 & $17.6-21.6$ & $16.7-23.9$ \\
Snout length & 4.2 & $3.7-7.6$ & $4.1-6.8$ \\
Eye length & 3.6 & $2.5-4.4$ & $3.4-7.4$ \\
Upper jaw length & 8.5 & $8.4-9.2$ & $7.5-10.5$ \\
Caudal-fin length & 32.1 & $26.7-53.6$ & $28.9-60.1$ \\
Pectoral-fin length & 17.0 & $15.1-20.6$ & $11.2-21.6$ \\
Pelvic-fin length & 17.6 & $14.2-18.8$ & $8.4-21.2$ \\
\hline
\end{tabular}

for G. oceanicus (Table 1). Apparent differences between these taxa may be attributable to individual variation. Another possibility is that the original image, although already stated herein as of reasonable quality, might be somewhat distorted and it is not so detailed, thus making measurements difficult and rendering differences in some body proportions such as caudal peduncle length.

Gobius boekeri is remarkably similar to Gobionellus oceanicus in all meristic characters (e.g. dorsal and anal fin counts, scales counts), and also in many features as presence of ctenoid scales on trunk, black round umeral blotch below first dorsal fin ray, and dark vertical stripe below eye, thus G. boekeri is herein regarded as a junior synonym of Gobionellus oceanicus.

Comparative material examined: Ctenogobius shufeldti. MZUSP 14346, 1 (55.3 mm), Brazil, Rio Grande do Sul, Lagoa de Tramandaí, Dec. 1973. Gobionellus oceanicus. MZUSP 10327, 2 (100.1; 150.0 mm), Brazil, Rio de Janeiro, Atafona, Dec. 1963. MZUSP 12771/12776, 3 (66.2-66.9 mm), Brazil, Rio de Janeiro, Ilha da Convivência, Atafona, Dec. 1963. MZUSP 46762, 2 (115.3; 135.7 mm), Brazil, Rio de Janeiro, Cabo Frio, lagoa de Araruama, em frente à Refinaria Nacional de Sal, Feb. 1983. MZUSP 65978, 1 (98 mm), Brazil, Bahia, Maragogipe, Barra do Paraguaçu 1245'S 3856'W, 10 Dec. 1974. MZUSP 66060, 5 (109.1-138.2 mm), Brazil, Bahia, Mercado de Santo Amaro, 14 Oct. 1971. MZUSP 66070, 1 (115.7 mm), Brazil, Rio de Janeiro, Atafona, Jul. 1963. MZUSP 12810/69666, 2 (122.3; 173.1 mm), Brazil, Rio de Janeiro, Atafona, Aug. 1963. MZUSP 79715, 1 (131.4 mm), United States, Florida, Suwanee River, Dec. 1963. MZUSP 82225, 2 (111.6; 112.0 mm), Brazil, Bahia, between Valença and Itacaré, 02-12 Sep. 2002.

\section{ACKNOWLEDGEMENTS}

I am grateful to Aléssio Datovo and Osvaldo Oyakawa for allowing access to infrastructure, Marcelo Roberto Souto de Melo and Hussam Zaher for supporting my participation in the project "Catálogo Taxonômico da Fauna 
do Brasil" (CNPq DTI-C Proc. 550259/2013-9). Henrique Varella provided images of Ctenogobius shufeldti; C. Ferrara and Gabi Szora did so for Gobius uranoscopus holotype. Dione Seripierri and Gustavo Rizzo kindly scanned the original descriptions of Gobius boekeri and G. silveiraemartinsi.

\section{REFERENCES}

Ahl, E 1931. Diagnosen einiger neuer sudamerikanischer Susswasserfische. Sitzungberichte der Gesellschaft Naturforschender Freunde zu Berlin, 1930: 405-409.

Birdsong, R.S. 1975. The osteology of Microgobius signatus Poey (Pisces: Gobiidae), with comments on other gobiid fishes. Bulletin of the Florida State Museum, Biological Sciences, 19(3): 135-187.

Birdsong, R.S. 1981. A review of the gobiid fish genus Microgobius Poey. Bulletin of Marine Science, 31(2): 267-306.

Cuvier, G. \& Valenciennes, A. 1837. Histoire naturelle des poissons. Suite du livre quatorzième. Gobioïdes. Livre quinzième. Acanthoptérygiens à pectorales pédiculées. v. 12: i-xxiv + 1-507 + 1p., Pls. 344-368.

Eigenmann, C.H. \& Eigenmann, R.S. 1888. A list of the American species of Gobiidae and Callionymidae, with notes on the specimens contained in the Museum of Comparative Zoölogy, at Cambridge, Massachusetts. Proceedings of the California Academy of Sciences (Series 2), 1(1): 51-78.

Fischer, L.G.; Pereira, L.E.D. \& Vieira, J.P. 2011. Peixes estuarinos e costeiros. Rio Grande, Luciano Fischer. 131p.

Fricke, R. \& Eschmeyer, W.N. 2019. Eschmeyer's Catalog of Fsishes: guide to fish collections. Available at: http://researcharchive.calacademy.org/ research/ichthyology/catalog/collections.asp. Access in: 05/09/2019.

Gilbert, C.R. \& Randall, J.E. 1979. Two new western Atlantic species of the gobiid fish genus Gobionellus, with remarks on characteristics of the genus. Northeast GulfScience, 3(1): 27-47.

Ginsburg, I. 1932. A revision of the genus Gobionellus (family Gobiidae). Bulletin of the Bingham Oceanographic Collection, Yale University, 4(2): $1-51$.

Ihering, H. 1893. Die Süsswasser-Fische von Rio Grande do Sul. Porto Alegre, Koseritz Deutscher Volkskalender. 36p.

Koumans, F.P. 1931. A preliminary revision of the genera of the gobioid fishes with united ventral fins. Proefschrift (Ph.D. Dissertation). Leiden, RijksUniversiteit. 174p.

Linnaeus, C. 1758. Systema Naturae, per regna tria naturae, secundum classes, ordines, genera, species, cum characteribus, differentiis, synonymis, locis. Tomus I. Editio decima, reformata). Holmiae. 824p.

Malabarba, L.R.; Carvalho Neto, P.; Bertaco, V.A.; Carvalho, T.P.; Santos, J.F. \& Artioli, L.G.S. 2013. Guia de identificação dos peixes da Bacia do Rio Tramandaí. Porto Alegre, Via Sapiens. 140p.

Miller, P.J. 1986. Gobiidae. In: Whitehead, P.J.P.; Bauchot, M.L.; Hureau, J.-C.; Nielsen, J. \& Tortonese, E. Fishes of the north-eastern Atlantic and Mediterranean, Paris: Unesco. v. 3, p. 1019-1085.
Miller, P.J. \& Smith, R.M.K. 1989. The West African species of Bathygobius (Teleostei: Gobiidae) and their affinities. Journal of Zoology, London, 218(2): 277-318.

Moura, R.L.; Figueiredo, J.L. \& Menezes, N.A. 2003. Família Gobiidae. In: Menezes, N.A.; Buclup, P.A.; Moura, R.L. \& Figueiredo, J.L. Catálogo de Peixes marinhos do Brasil. São Paulo, Museu de Zoologia da USP. p. 97-100.

Murdy, E.0. 1998. A review of the gobioid fish genus Gobioides. Ichthyological Research, 45(2): 121-133.

Murdy, E.0. \& Hoese, D.F. 2003. Gobiidae. In: Carpenter, K.E. 2003. The living marine resources of the Western Central Atlantic. Volume 3: Bony fishes part 2 (Opistognathidae to Molidae). FAO species identification guide for fishery purposes and American Society of Ichthyologist and Herpetologists Special Publication № 5. Rome, FA0. v. 3, p. 1781-1796.

Nelson, J.S.; Grande, T.C. \& Wilson, M.V.H. 2016. Fishes of the World. 5.ed. Hoboken, John Wiley \& Sons. v-xli, 707p.

Pezold, F.L. 2004. Redescriptions and synonymies of species of the AmericanWest African genus Gobionellus (Teleostei, Gobiidae) with a key to species. Copeia, 2004(2): 281-297.

Pinchuk, V.I. 1976. Systematics of the goby, genera Gobius Linné (native species), Neogobius Iljinu [sic] and Mesogobius Bleeker. Journal of Ichthyology, 16(4): 543-552.

Pinchuk, V.I. 1977. The systematics of gobies of the genera Gobius Linne (native species), Neogobius Iljin and Mesogobius Bleeker. Journal of Ichthyology, 17(4): 517-525

Rodríguez-Rey, G.T.; Carvalho-Filho, A. Araújo, M.E. \& Solé-Cava, A.M. 2017. Evolutionary history of Bathygobius (Perciformes: Gobiidae) in the Atlantic biogeographic provinces: a new endemic species and old mitochondrial lineages. Zoological Journal of the Linnean Society, 182(2): 360-384.

Sauvage, H.E. 1882. Description de quelques poissons de la collection du Muséum d'histoire naturelle. Bulletin de la Société philomathique de Paris, 7 Série, 6: 168-176.

Tornabene, L.; Baldwin, C.; Weigt, L.A. \& Pezold, F. 2010. Exploring the diversity of western Atlantic Bathygobius (Teleostei: Gobiidae) with cytochrome c oxidase-l, with description of two new species. Aqua, International Journal of Ichthyology, 16(4): 141-170.

Van Tassell, J.L.; Joyeux, J.-C.; Macieira, R.M. \& Tornabene, L. 2015. Status of Gobiosoma (Teleostei: Gobiidae) from Brazil: description of a new species, redescription of $G$. hemigymnum, molecular phylogeny of the genus, and key to Atlantic species. Zootaxa, 4007(4): 451-480.

Watson, R.E. 1996. Revision of the subgenus Awaous (Chonophorus) (Teleostei: Gobiidae). Ichthyological Exploration of Freshwaters, 7(1): 1-18.

Watson, R.E. 2000. Sicydium from the Dominican Republic with description of a new species (Teleostei: Gobiidae). Stuttgarter Beiträge zur Naturkunde. Serie A, Biologie, 608: 1-31. 